\title{
Analisis Biaya Satuan Operasional Penyelenggaraan Taman Kanak-Kanak Holistik Integratif
}

\author{
Novrian Satria Perdana ${ }^{\bowtie}$ \\ Pusat Penelitian Kebijakan, Balitbang dan Perbukuan, Kemendikbud \\ DOI: $\underline{10.31004 / o b s e s i . v 5 i 1.501}$
}

Email:

\begin{abstract}
Abstrak
Hingga saat ini semakin banyak yang masyarakat yang mengeluh mahalnya biaya TK, meskipun Pemerintah telah berupaya memberikan bantuan dana. Dalam pemberian bantuan dana hendaknya memperhatikan perhitungan biaya satuan siswa, oleh karena itu tujuan penelitian untuk (1) menghitung besaran biaya satuan operasional (BSO) penyelenggaraan TK holistik integratif, dan (2) menghitung variasi dan proyeksi besaran biaya satuan operasional penyelenggaraan TK holistik integratif menurut kategori wilayah. Penelitian ini menggunakan data kuantitatif menggunakan metode activity based costing, dengan sampel penelitian ini sebanyak 577 TK di Indonesia. Unit analisis penelitian ini adalah lembaga TK. Penelitian ini menggunakan kuesioner secara online yang dikirimkan kepada seluruh lembaga PAUD di Indonesia. Simpulan penelitian ini adalah (1) biaya satuan operasional selama 1 tahun per siswa untuk TK holistik integratif sebesar Rp 5.857.750, dan (2) besaran biaya satuan operasional untuk TK di Indonesia bagian Barat lebih rendah daripada Indonesia bagian tengah dan timur.
\end{abstract}

Kata Kunci: $t k$; biaya satuan operasional; activity based costing.

\begin{abstract}
Until now more and more people are complaining about the high cost of kindergarten, even though the Government has tried to provide financial assistance. In granting financial assistance should pay attention to the calculation of student unit costs, therefore the research objectives are to (1) calculate the amount of operational unit costs (BSO) for the implementation of integrative holistic kindergarten, and (2) calculate variations and projections of the operational unit costs for implementing integrated holistic kindergarten region category. This study uses quantitative data using activity based costing methods, with a sample of this study as many as 577 kindergarten in Indonesia. The unit of analysis of this research is kindergarten institution. This study uses an online questionnaire sent to all PAUD institutions in Indonesia. The conclusions of this study are (1) operational unit costs for 1 year for integrative holistic kindergartens of $\operatorname{Rp} 5,857,750$, and (2) The cost of operating units for kindergarten in West Indonesia is lower than that of central and eastern Indonesia.
\end{abstract}

Keywords: kindergarten; operational unit cost; activity based costing.

Copyright (c) 2020 Novrian Satria Perdana

$\triangle$ Corresponding author:

Email Address : novrian1711@gmail.com (Jakarta, Indonesia)

Received 13 March 2020, Accepted 1 May 2020, Published 2 May 2020 


\section{PENDAHULUAN}

Pendidikan Anak Usia Dini (PAUD) merupakan pendidikan yang paling fundamental karena perkembangan anak di masa selanjutnya sangat ditentukan oleh berbagai stimulasi bermakna yang diberikan sejak usia dini. Menurut hasil penelitian yang dilakukan oleh Dr. Benyamin S. Bloom, menyampaikan bahwa pertumbuhan sel jaringan otak pada anak usia 0-4 tahun mencapai 50\% (Cropley, 1999). Artinya pendidikan anak usia dini seharusnya dimulai pada jenjang usia nol sampai empat tahun. Anak usia dini berada dalam masa keemasan di sepanjang rentang usia perkembangan manusia.

Menurut Fauziddin (2016), pada tahapan usia dini pertumbuhan dan perkembangan mulai dan sedang berlangsung, seperti perkembangan fisiologis, bahasa, sosial emosional, motorik dan kognitif. Perkembangan ini akan menjadi dasar bagi perkembangan anak selanjutnya. Disamping itu anak usia dini ialah anak yang berumur dari nol sampai delapan tahun, anak usia dini juga termasuk individu yang unik, kenapa disebut unik ya karena mereka dilahirkan dengan memiliki minat, bakat dan potensi yang berbeda yang diberikan oleh Allas Swt (Hasanah \& Muryanti, 2019). Senada dengan pernyataan tersebut Trimuliana, Dhieni, \& Hapidin (2019) menyatakan tujuan utama pendidikan adalah untuk membentuk kepribadian anak yang berkarakter.

Undang-undang nomor 20 tahun 2003 tentang Sistem Pendidikan Nasional (Kementerian Pendidikan dan Kebudayaan, 2003) menyatakan bahwa pendidikan anak usia dini adalah upaya pembinaan untuk anak sejak lahir sampai dengan usia enam tahun yang dilakukan melalui pemberian rangsangan pendidikan, untuk membantu pertumbuhan dan perkembangan jasmani dan rohani agar anak memiliki kesiapan dalam memasuki pendidikan lebih lanjut. Pendidikan anak usia dini diarahkan untuk memfasilitasi tumbuh kembang anak secara sehat dan optimal sesuai dengan nilai, norma, dan harapan masyarakat (Kebudayaan, 2011). PAUD sangat penting dan mendasar sebab merupakan hulu dalam pengembangan sumber daya manusia. Periode emas (Golden Period) dalam tumbuh kembang anak hanya terjadi sekali dalam kehidupan manusia yang dimulai sejak lahir. Kesadaran akan pentingnya penyelenggaraan PAUD pada saat ini telah tumbuh sebagai sebuah kesadaran kolektif antara masyarakat dan pemerintah.

Realitas di lapangan menunjukkan bahwa hampir seluruh lembaga PAUD dan sejenisnya terselenggara atas prakarsa dan swadaya masyarakat. Bahkan Anhusadar (2016) terkait dengan pentingnya lembaga PAUD menyatakan pemikiran kreatif berhubungan secara langsung dengan penambahan nilai, penciptaan nilai, serta penemuan peluang lembaga pendidikan anak usia dini. Kebijakan Direktorat Jenderal PAUD dan Dikmas adalah memperluas layanan PAUD berkualitas melalui ketersediaan Satuan PAUD yang mudah diakses, pendidik yang sesuai dengan kompetensi yang diharapkan, peningkatan kualitas partisipasi masyarakat dalam PAUD, dan dukungan penyelenggaraan PAUD dari Pusat, Daerah, serta masyarakat. Salahsatu indicator meluasnya akses pendidikan adalah Angka Partisipasi Kasar (APK).

Menurut BPS yang tertera dalam laman resminya, APK adalah perbandingan antara jumlah penduduk yang masih bersekolah di jenjang pendidikan tertentu (tanpa memandang usia penduduk tersebut) dengan jumlah penduduk yang memenuhi syarat resmi penduduk usia sekolah di jenjang pendidikan yang sama. Kondisi saat ini, meskipun telah banyak upaya Pemerintah untuk memperluas akses PAUD, namun sayangnya laju pergerakan APK cenderung turun dari tahun 2015 sebesar 35.18 hingga 2017 berada pada angka 33.84 dan mengalami kenaikan pada tahun 2018 menjadi 37.92 dan kembali turun pada angka 36.93 di tahun 2019 (gambar 1). 


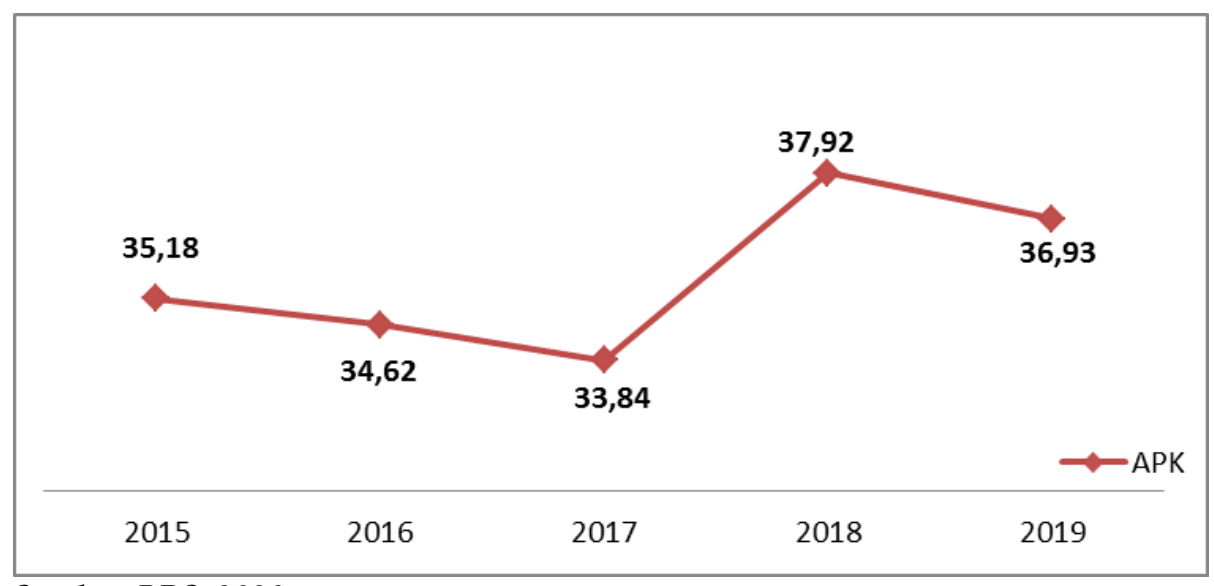

Sumber: BPS, 2020

Gambar 1. Perkembangan APK PAUD tahun 2015-2019

Tren menurunnya partisipasi mengakses PAUD salahsatunya diindikasikan karena mahalnya biaya untuk menyekolahkan anak di PAUD. Fenomena tingginya biaya pendidikan merupakan permasalahan yang dihadapi oleh seluruh kalangan masyarakat pada hampir seluruh jenjang khususnya pada sekolah yang diselenggarakan oleh swasta. Terdapat informasi terkait mahalnya besaran biaya anak masuk di beberapa TK Swasta Jakarta mencapai Rp 8.000.000 untuk SPP per bulan dan Rp 41.800 .000 untuk uang pangkal (ibupedia.com, 2019). Tingginya biaya TK tersebut juga dirasakan di Banjarmasin. Menurut laman yang dilansir oleh kalsel.prokal.co pada tahun 2020, seorang ibu-ibu usia 35 tahun itu tidak menginginkan anaknya masuk TK. Alasannya yaitu ongkos masuk TK tidaklah murah, beliau harus membayar uang pendaftaran Rp 1.200.000. Dengan iuran bulanan sebesar Rp 125.000. Sebagai karyawati perusahaan swasta yang gajinya belum memenuhi standar UMR (Upah Minimum Regional), besarnya biaya tersebut memang cukup membebani. Mahalnya biaya tersebut sangat disayangkan, karena menurut Dirjen PAUD DIKMAS seperti yang dikutip dalam laman news.detik.com (2019) menyampaikan bahwa pada prinsipnya yayasan sosial tidak boleh mencari untung berlebihan. Beliau menegaskan bahwa yayasan itu bukanlah korporasi yang tujuannya mencari untung. Mahalnya biaya tersebut salahsatunya untuk menyelenggarakan TK sesuai standar kualitas nasional yang tertuang dalam Permendikbud Nomor 137 tahun 2014.

Taman Kanak-kanak adalah salah satu bentuk satuan pendidikan anak usia dini pada jalur pendidikan formal yang menyelenggarakan program pendidikan bagi anak usia empat tahun sampai enam tahun, yang bertujuan untuk membina tumbuh kembang anak usia lahir sampai enam tahun secara menyeluruh, yang mencakup aspek fisik dan nonfisik, dengan memberikan rangsangan bagi perkembangan jasmani, rohani, motorik, akal pikiran, emosional, dan sosial yang tepat agar anak dapat tumbuh dan berkembang secara optimal serta menghubungkan antara pendidikan keluarga dengan pendidikan sekolah.

Dalam upaya mengurangi beban biaya orangtua menyekolahkan anaknya di TK dan dalam rangka memperluas layanan yang berkualitas, pemerintah mengalokasikan dana Bantuan Operasional Penyelenggaraan PAUD. Program BOP ditujukan kepada anak usia 0-6 tahun, dengan prioritas anak dari keluarga kurang mampu, berkebutuhan khusus, dan layanan khusus. BOP diberikan kepada anak melalui lembaga PAUD untuk mendukung proses operasional pembelajaran dan dukungan biaya personal bagi anak PAUD. Kementerian Pendidikan dan Kebudayaan mengalokasikan anggaran sebesar Rp 4,47 triliun untuk bantuan operasional penyelenggaraan pendidikan anak usia dini (BOP PAUD) pada 2019. Jumlah ini naik 10 persen dibanding tahun 2018 yang sebesar Rp 4,07 triliun. Direktur Jenderal PAUD dan Dikmas Harris Iskandar mengatakan, bantuan tersebut akan diberikan kepada 7.459.167 anak dengan nominal sebesar Rp 600 ribu per anak. Dalam penyaluran anggaran tersebut juga dilakukan monitoring meskipun tidak seluruh kabupaten/kota 
dikunjungi langsung oleh Tim Pusat. Upaya monitoring dan evaluasi BOP juga melibatkan Pemda sehingga dapat meminimalisir penyalahgunaan anggaran. Adanya bantuan dana tersebut adalah untuk meningkatkan aksesibilitas anak memperoleh pendidikan di PAUD. Menurut Carneiro dalam Perdana (2015) memberikan pokok-pokok pikirannya bahwa ada dua perlakuan aksesibilitas, yaitu a) aksesibilitas keuangan yang diartikan sebagai "kemampuan individu", seperti kemampuan membayar biaya pendidikan (financial accessibility, defined as the individual ability to pay for education) dan b) apa saja yang berhubungan dengan aksesibilitas fisik.

BOP PAUD diatur dalam Peraturan Menteri Pendidikan dan Kebudayaan Nomor 2 tahun 2018 tentang Petunjuk Teknis Penggunaan Dana Alokasi Khusus Nonfisik Bantuan Operasional Penyelenggaraan PAUD tahun 2018. Berdasarkan peraturan tersebut, sebanyak 50 persen dana BOP PAUD harus digunakan untuk kegiatan pembelajaran dan bermain, seperti membeli kertas, spidol, krayon, serta penyelenggarakan kegiatan pendidikan keluarga atau parenting. Sebanyak 35 persen untuk kegiatan pendukung, antara lain membeli obat-obatan ringan, dan menambah biaya transpor pendidik. Sedangkan 15 persen sisanya untuk kegiatan lain, yaitu perawatan sarana dan prasarana, membayar telepon, listrik, dan internet.

\section{Pembiayaan Pendidikan}

Pembiayaan pendidikan merupakan kegiatan yang berhubungan dengan diterimanya pendapatan keuangan yang diperoleh sekolah dari dana APBN, APBD dan masyarakat atau orang tua serta digunakan untuk membiayai setiap program pendidikan yang dirancang (Akdon, 2015) dan (Ulpha dan Kurniady, 2016). Pidarta (2013) dalam bukunya menjelaskan bahwa faktor ekonomi merupakan faktor yang cukup menentukan keberhasilan pendidikan, karena dengan ekonomi yang memadai maka 1) sarana dan prasarana, media, alat belajar, dan lainnya dapat dipenuhi, 2) proses belajar mengajar bisa dilaksanakan secara lebih intensif, sebab pendidik dapat fokus tanpa mencari sambilan di luar, dan 3) motivasi dan gairah kerja personalia pendidikan meningkat, sehingga mereka juga siap meningkatkan profesi.

Biaya pendidikan adalah cost yang harus dikeluarkan untuk membiayai kegiatan terkait dalam pendidikan. Nanang Fattah dalam Afmansyah (2019) menyebutkan biaya dalam pendidikan meliputi biaya langsung (direct cost) dan biaya tidak langsung (indirect cost). Biaya langsung terdiri dari biaya-biaya yang dikeluarkan untuk keperluan pelaksanaan pengajaran dan kegiatan belajar siswa, sedangkan biaya tidak langsung berupa keuntungan yang hilang dalam bentuk biaya kesempatan yang hilang yang dikorbankan oleh siswa selama belajar. Ada beberapa cara dalam memperkirakan biaya pendidikan, menurut Munandar dalam Afmansyah (2019) menyebutkan cara tersebut antara lain: (1) memperkirakan biaya atas dasar sumber-sumber pembiayaan, dan (2) memperkirakan biaya atas dasar laporan dari lembaga-lembaga pendidikan.

Fungsi ekonomi pendidikan adalah untuk menunjang kelancaran proses pendidikan dan sebagai bahan pelajaran untuk membentuk manusia ekonomi. Tiap lembaga pendidikan harus mampu mengupayakan pendanaan pendidikan untuk menutupi kebutuhan layanan pendidikan dengan mencari dari berbagai sumber selain dari Pemerintah atau yayasan. Semakin banyak dana yang diperoleh maka pendidikan akan dapat diselenggarakan dengan optimal, sehingga tujuan pendidikan akan lebih mudah tercapai. Menurut Ulpha dan Kurniady (2016), dana pendidikan perlu dikelola secara professional, pelaksanaannya diawasi secara ketat, dan dipertanggungjawabkan dengan bukti-bukti yang sah. Semua penggunan dana pada setiap kegiatan perlu dilakukan secara efisien dan efektif. Konsep produksi harus dipegang oleh lembaga penyelenggara pendidikan, yaitu upaya efisiensi pendidikan yang meliputi penggunaan dana, proses kegiatan, dan hasil kegiatan. Ketiganya harus berjalan selaras agar tidak terjadi hambatan dalam mencapai tujuan pendidikan yang 
telah disepakati. Fungsi produksi ekonomi akan bisa diaplikasikan dengan baik, bila ada jaminan bahwa peserta didik segera bekerja setelah lulus.

Dalam pemberian bantuan penyelenggaraan PAUD khususnya TK perlu diperhatikan besaran dana yang diberikan agar dapat digunakan untuk membiayai operasional TK di seluruh Indonesia. Masih banyaknya keluhan di masyarakat mengenai mahalnya biaya menyekolahkan anaknya di TK membuktikan bahwa besaran dana BOP yang diberikan oleh Pemerintah sebesar Rp 600.000/siswa/tahun dirasa masih kurang. Sehingga sudah saatnya Pemerintah memberikan bantuan dana berdasarkan perhitungan biaya satuan yang sesungguhnya terjadi di lapangan. Penelitian biaya satuan TK pernah dilakukan oleh (Chrystiana, N., Mochamad, 2014), yang menyimpulkan bahwa komponen biaya pada pendidikan TK terdiri dari (1) biaya operasi personalia berupa biaya gaji; (2) biaya operasi non personalia berupa biaya (a) proses pendidikan, (b) kelembagaan, (c) administrasi sekolah, (d) komite sekolah, dan (e) perawatan dan perbaikan ringan. BSOP di TK half-day adalah Rp 1.270.038,00/tahun/siswa dan Rp 1.454.389,00/tahun/siswa, sedangkan BSOP di TK full-day adalah Rp 10.466.134,00/ tahun/siswa.

Dalam menjawab fakta di lapangan mengenai mahalnya biaya TK dan untuk membantu Pemerintah dalam menentukan besaran bantuan dana untuk TK, maka penelitian ini mencoba menghitung besaran biaya satuan TK Holistik Integratif (HI). Pengembangan PAUD HI adalah upaya pengembangan anak yang dilakukan untuk memenuhi kebutuhan esensial anak yang beragam dan saling terkait secara simultan, sistematis, dan terintegrasi sesuai masa tumbuh kembangnya. Agar penyelenggaraan PAUD khususnya TK lebih bersifat holistik, dalam juknis penyelenggaraan PAUD Holistik Integratif (2015) disebutkan pelayanan minimal terdiri dari: (1) layanan pendidikan, (2) layanan kesehatan, gizi, dan perawatan, (3) layanan pengasuhan, (4) layanan perlindungan, dan (5) layanan kesejahteraan. Berdasarkan uraian kasus dan penjelasan di atas, maka tujuan penelitian antara lain untuk (1) menghitung besaran biaya satuan operasional (BSOP) penyelenggaraan TK holistik integratif, dan (2) menghitung variasi dan proyeksi besaran biaya satuan operasional penyelenggaraan TK holistik integratif menurut kategori wilayah.

Untuk menjawab tujuan penelitian tersebut, perhitungan biaya berdasarkan aktivitas (ABC). Menurut Hongren dalam Syawalaxa, dkk (2019) dan Cardos, I.R. \& Pete (2011), ABC sistem adalah suatu sistem biaya yang mengumpulkan biaya-biaya ke dalam aktivitasaktivitas yang terjadi dalam perusahaan lalu membebankan biaya atau aktivitas tersebut kepada produk atau jasa, dan melaporkan biaya aktivitas dan produk atau jasa tersebut pada manajemen agar selanjutnya dapat digunakan untuk perencanaan, pengendalian biaya, dan pengambilan keputusan. Selanjutnya yang dimaksud aktivitas dalam ABC sistem adalah setiap kejadian atau transaksi yang merupakan pemicu biaya (cost driver) yakni, bertindak sebagai faktor penyebab dalam pengeluaran biaya dalam organisasi. Aktivitasaktivitas ini menjadi titik perhimpunan biaya. Dalam sistem ABC, biaya ditelusuri ke aktivitas dan kemudian ke produk. Sistem ABC mengasumsikan bahwa aktivitasaktivitaslah, yang mengkonsumsi sumber daya dan bukannya produk.

\section{METODOLOGI}

Penelitian ini menggunakan pendekatan kuantitatif, dengan menggunakan pendekatan penghitungan biaya berbasis aktivitas (Activity Based Costing/ABC). Metode pemilihan sampel yang digunakan dalam penelitian ini adalah Random Sampling. Unit analisis penelitian ini adalah TK. Populasi penelitian ini adalah seluruh lembaga PAUD di Indonesia. Sampel penelitian ini yaitu yang mengembalikan isian kuesioner online yang dikirimkan, yaitu sebanyak 577 TK. Salah satu kriteria utama sampel adalah bahwa ia harus dapat mewakili populasi baik secara proporsi maupun karakteristik (McMillan dkk, 2010). Setelah kuesioner terisi oleh lembaga di masing-masing daerah, penarikan sampel dilakukan secara berjenjang dari tingkat wilayah, provinsi, hingga kabupaten/kota. Indonesia dibagi 
ke dalam 6 wilayah, yaitu (1) wilayah Jawa; (2) wilayah Sumatera; (3) wilayah Sulawesi; (4) wilayah Kalimantan; dan (5) wilayah Bali-Nusa Tenggara, dan (6) wilayah Maluku Papua.

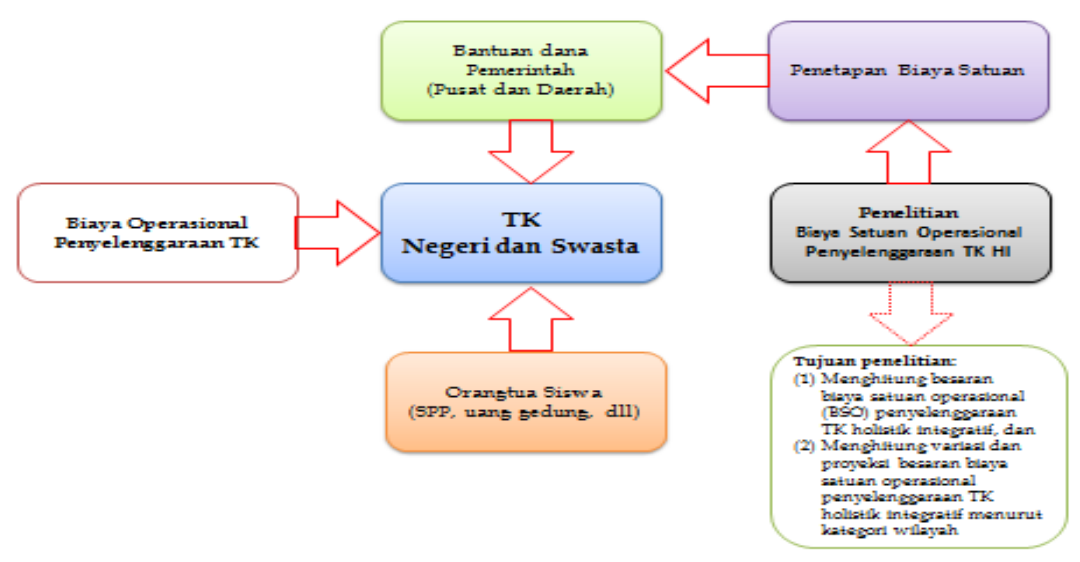

Gambar 2. Desain Penelitian

Penelitian ini didasarkan atas banyaknya keluhan masyarakat terkait mahalnya biaya menyekolahkan anaknya di TK. Fakta menunjukkan bahwa bantuan dari Pemerintah Pusat dan Daerah dalam membantu biaya operasional penyelenggaraan TK sudah diberikan namun kemungkinan jumlahnya kurang mencukupi yang dibuktikan dari masih banyaknya TK memungut biaya kepada orangtua siswa. Pemerintah dalam memberikan bantuan dana hendaknya dapat memperhatikan kebutuhan biaya operasional penyelenggaraan TK secara riil sehingga bantuan yang diberikan bisa mencukupi. Tujuan dilakukannya penelitian ini adalah untuk memberikan gambaran kepada Pemerintah tentang besaran nilai biaya satuan operasional penyelenggaraan TK Holistik Integratif (gambar 2).

Instrumen penelitian ini adalah kuesioner terstruktur yang dikembangkan berdasarkan pertanyaan dan tujuan penelitian. Komponen kuesioner untuk menentukan besaran dana operasional penyelenggaraan PAUD berasal dari Permendikbud 4 Tahun 2019 tentang Juknis Penggunaan DAK Nonfisik BOP PAUD 2019 disesuaikan dengan laporan keuangan TK yang telah dikelompokkan berdasarkan aktifitas layanan yang dilakukan dalam penyelenggaraan TK HI. Data yang diperoleh yang bersumber dari laporan keuangan riil pada masing-masing lembaga kemudian diolah menurut komponen biaya kemudian dihitung menurut kategori wilayah dan dilakukan proyeksi hingga tahun 2022.

\section{HASIL DAN PEMBAHASAN \\ Profil Responden}

Berdasarkan hasil kuesioner online yang terkumpul, terdapat responden sebanyak 577 TK. Berdasarkan gambar 3, status akreditasi TK yang terbanyak adalah B dengan jumlah 266 TK (46\%), tidak terakreditasi sebanyak 189 (33\%), terakreditasi C sebanyak 68 (12\%), dan terakreditasi A sebanyak 54 (9\%).

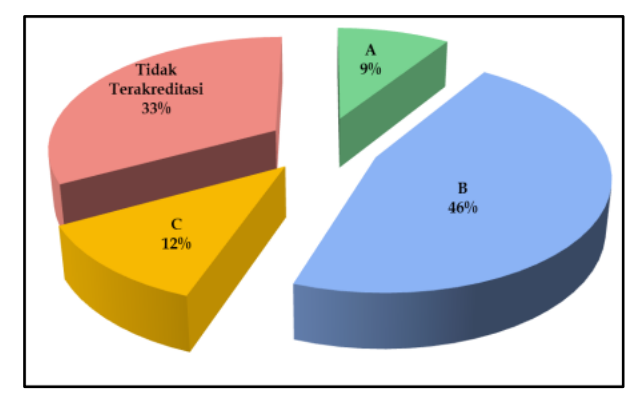

Sumber: hasil pengolahan data

Gambar 3. Profil Responden 
Menurut Habiburrahman (2020), akreditasi sangat penting khususnya bagi lembaga karena dapat membantu untuk mengetahui sejauhmana dirinya telah memenuhi kriteria mutu yang sudah ditetapkan pemerintah atau standar nasional pendidikan sebagai standar minimal kualitas (minimum standards of quality); sebagai referensi bagi semua pihak pada lembaga untuk melakukan evaluasi terhadap kinerja lembaga (institution's performance) dan perencanaan jangka pendek dan jangka panjang (short and long terms planning); sebagai dasar untuk melakukan perbaikan dan peningkatan mutu pendidikan pada masa yang akan datang sebagai bagian dari peningkatan mutu berkelanjutan (sustainable quality improvement); dan sebagai bentuk kepatuhan (compliance) terhadap regulasi yang ditetapkan pemerintah serta sebagai bagian dari akuntabilitas publik (public accountability). Mengingat pentingnya akeditasi untuk PAUD yang sejatinya memiliki peran penting dalam mewujudkan generasi emas bangsa, sudah seharusnya lembaga dan Pemerintah saling bersinergi untuk menjalankan proses akreditasi lembaga agar terjadi pemenuhan standar pendidikan yang dituangkan dalam Permendikbud Nomor 13 Tahun 2018 tentang Badan Akreditasi Nasional Sekolah/Madrasah dan Badan Akreditasi Nasional Pendidikan Anak Usia Dini dan Pendidikan Nonformal.

\section{Biaya Operasional TK Holistik Integratif Menurut Komponen Pengeluaran}

Biaya pendidikan adalah cost yang harus dikeluarkan untuk membiayai kegiatan terkait dalam pendidikan. Nanang Fattah dalam Afmansyah (2019) menyebutkan biaya dalam pendidikan meliputi biaya langsung (direct cost) dan biaya tidak langsung (indirect cost). Biaya langsung terdiri dari biaya-biaya yang dikeluarkan untuk keperluan pelaksanaan pengajaran dan kegiatan belajar siswa, sedangkan biaya tidak langsung berupa keuntungan yang hilang dalam bentuk biaya kesempatan yang hilang yang dikorbankan oleh siswa selama belajar. Ada beberapa cara dalam memperkirakan biaya pendidikan, menurut Munandar dalam Afmansyah (2019) menyebutkan cara tersebut antara lain: (1) memperkirakan biaya atas dasar sumber-sumber pembiayaan, dan (2) memperkirakan biaya atas dasar laporan dari lembaga-lembaga pendidikan. Penelitian ini membahas hasil dari laporan keuangan masing-masing TK yang ada seluruh Indonesia dengan jumlah sampel sebanyak 577 TK. Dalam menyusun biaya satuan operasional, dihitung menurut komponen pengeluaran pada tahun sebelumnya yaitu 2019. Adapun beberapa uraian komponen dalam menentukan biaya satuan operasional TK holistik integratif adalah sebagai berikut:

\section{Gaji Guru dan Tenaga Kependidikan}

Tabel 1. Pengeluaran untuk Gaji Guru dan Tenaga Kependidikan

\begin{tabular}{|l|r|r|r|}
\hline \multicolumn{1}{|c|}{ Jabatan } & $\begin{array}{c}\text { Jam Kerja per } \\
\text { Bulan }\end{array}$ & Gaji per bulan & Gaji per jam \\
\hline Kepala TK & 90 & $1,735,000$ & 19,278 \\
\hline Guru TK & 90 & $1,343,000$ & 14,922 \\
\hline Guru Pendamping & 90 & $1,025,000$ & 11,389 \\
\hline Tenaga Administrasi & 90 & 979,000 & 10,878 \\
\hline \multicolumn{2}{|c|}{ Jumlah Gaji per Jam } & $\mathbf{6 0 , 9 8 4 , 0 0 0}$ \\
\hline \multicolumn{2}{|c|}{ Jumlah Gaji per Tahun (1080 jam) } \\
\hline
\end{tabular}

Guru dan tenaga kependidikan merupakan komponen utama dalam penyelenggaraan proses kegiatan belajar mengajar di TK. Dalam penelitian ini hanya menghitung besaran dana yang dikeluarkan untuk membiayai gaji/honor guru dan tenaga kependidikan. Berdasarkan hasil perhitungan angka dari hasil kuesioner yang tercantum pada tabel 1 di atas, pada tahun 2019 rata-rata jam kerja per bulan untuk guru dan tenaga kependidikan adalah 90 jam dan selama setahun sebesar 1.080 jam. Selanjutnya besaran 
pengeluaran TK untuk membiayai komponen jumlah gaji per tahun sebesar Rp 60.984.000. adapun besaran dana ini dengan rata-rata jam kerja sebesar 90 jam per bulan. besaran biaya yang terbesar tentunya digunakan untuk membiayai kepala TK yaitu sebesar Rp 1.735.000 per bulan, dan yang terkecil untuk tenaga administrasi sebesar Rp 979.000 per bulan.

\section{Pengembangan SDM Guru/Tendik}

Tabel 2. Pengeluaran untuk Pengembangan SDM Guru/Tendik

\begin{tabular}{|l|r|r|r|}
\hline \multicolumn{1}{|c|}{ Bentuk Kegiatan } & Volume per Tahun & $\begin{array}{c}\text { Biaya yang } \\
\text { dikeluarkan }\end{array}$ & \multicolumn{1}{|c|}{ Total Biaya } \\
\hline Pelatihan (pembiayaan sekolah) & 2 & 235,000 & 470,000 \\
\hline Studi Banding & 1 & 157,000 & 157,000 \\
\hline Magang & 1 & 232,000 & 232,000 \\
\hline \multicolumn{2}{|c|}{ Jumlah Biaya Pengembangan SDM } & 859,000 \\
\hline
\end{tabular}

Dalam menunjang kemampuan guru dan tenaga kependidikan, maka setiap tahunnya sebagian besar TK mengadakan kegiatan pengembangan kompetensi guru dan tenaga kependidikan tersebut. Berdasarkan hasil perhitungan dari kuesioner, pada tabel 2 disampaikan bahwa diperlukan dana sebesar Rp 859.000 pada tahun 2019 untuk membiayai kegiatan tersebut. Adapun komponen terbesar adalah digunakan untuk pelatihan yang diadakan 2 kali dalam setahun, yaitu sebesar Rp 470.000 .

\section{Penyuluhan Gizi Seimbang Bagi Orangtua Anak}

Tabel 3.Pengeluaran untuk Penyuluhan Gizi Seimbang Bagi Orangtua Anak

\begin{tabular}{|l|c|c|r|}
\hline \multicolumn{1}{|c|}{ Komponen Pengeluaran } & Volume per Tahun & $\begin{array}{c}\text { Biaya yang } \\
\text { dikeluarkan }\end{array}$ & Total Biaya \\
\hline Honorarium penyuluh & 2 & 250,000 & 500,000 \\
\hline Konsumsi peserta & 2 & 289,000 & 578,000 \\
\hline \multicolumn{2}{|c|}{ Jumlah Biaya Penyuluhan Gizi Seimbang } & $1,078,000$ \\
\hline
\end{tabular}

Gizi merupakan salah satu faktor lingkungan dan merupakan penunjang agar proses tumbuh kembang tersebut dapat baik. Hal ini berarti pemberian makanan yang berkualitas dan kuantitasnya baik menunjang tumbuh kembang (Syafriani, 2016). Mengingat pentingnya gizi bagi tumbuhkembang anak, maka sebagian besar TK mengadakan kegiatan penyuluhan gizi seimbang bagi orangtua anak. Berdasarkan hasil perhitungan dari jawaban kuesioner, tercantum hasilnya pada tabel 3 yaitu pada tahun 2019 rata-rata penyelenggaraannya sebanyak 2 kali dalam setahun dengan total biaya sebesar Rp 1.078.000.

\section{Penyediaan Makanan Tambahan Anak}

Tabel 4. Pengeluaran untuk Penyediaan Makanan Tambahan Anak

\begin{tabular}{|l|c|r|r|}
\hline \multicolumn{1}{|c|}{ Komponen Pengeluaran } & Volume per Tahun & $\begin{array}{c}\text { Biaya yang } \\
\text { dikeluarkan }\end{array}$ & \multicolumn{1}{|c|}{ Total Biaya } \\
\hline Honorarium juru masak & 6 & 150,000 & 900,000 \\
\hline Bahan makanan & 6 & 212,500 & $1,275,000$ \\
\hline \multicolumn{3}{|c|}{ Jumlah Biaya Penyediaan Makanan Tambahan Anak } & $\mathbf{2 , 1 7 5 , 0 0 0}$ \\
\hline
\end{tabular}


Berdasarkan hasil perhitungan dari jawaban kuesioner, tercantum hasilnya pada tabel 4 yaitu pada tahun 2019 setiap TK mengeluarkan dana sebesar Rp 2.175 .000 untuk keperluan penyediaan makanan tambahan anak yang dilakukan sebanyak 6 kali dalam satu tahun. Adapun biaya terbesar digunakan untuk pembelian bahan makanan seperti ayam, ikan, sayuran, dan sebagainya. Menurut penelitian yang dilakukan oleh Rahayu dan Munastiwi (2018), pemberian makanan tambahan pada anak dapat memberikan dampak langsung dan tidak langung. Adapun dampak langsung, yaitu: sumber energi dan emosi senang, dan dampak tidak langsung, yaitu: anak suka makan sayur, anak terbiasa tertib, dan anak dapat bertanggungjawab.

\section{Pemeriksaan Kesehatan Anak}

Tabel 5. Pengeluaran untuk Pemeriksaan Kesehatan Anak

\begin{tabular}{|l|c|c|r|}
\hline \multicolumn{1}{|c|}{ Komponen Pengeluaran } & Volume per Tahun & $\begin{array}{c}\text { Biaya yang } \\
\text { dikeluarkan }\end{array}$ & \multicolumn{1}{|c|}{ Total Biaya } \\
\hline Jasa Tenaga Kesehatan & 2 & 150,000 & 300,000 \\
\hline Obat/Vitamin & 2 & 162,000 & 324,000 \\
\hline \multicolumn{2}{|c|}{ Jumlah Biaya Pemeriksaan Kesehatan Anak } & 624,000 \\
\hline
\end{tabular}

Kesehatan sangatlah penting bagi anak usia dini bahkan mempengaruhi kecerdasan otak anak (Khotimah, 2014), sehingga sangat penting bagi lembaga PAUD khususnya TK mengadakan pemeriksaan kesehatan anak didik secara rutin. Berdasarkan hasil perhitungan dari jawaban kuesioner, tercantum hasilnya pada tabel 5 yaitu pada tahun 2019 rata-rata setiap TK mengadakan pemeriksaan kesehatan anak sebanyak 2 kali dalam setahun. Adapun jumlah biaya yang dikeluarkan dalam satu tahun melakukan pemeriksaan kesehatan sebesar Rp 624.000, dengan komponen pengeluaran yang terbesar digunakan untuk pembelian obat/vitamin untuk anak-anak.

\section{Kegiatan Pertemuan Dengan Orang Tua/Wali Murid}

Tabel 6. Pengeluaran untuk Kegiatan Pertemuan Dengan Orang Tua/Wali Murid

\begin{tabular}{|l|c|r|r|}
\hline \multicolumn{1}{|c|}{ Komponen Pengeluaran } & Volume per Tahun & $\begin{array}{c}\text { Biaya yang } \\
\text { dikeluarkan }\end{array}$ & Total Biaya \\
\hline Honorarium Narasumber & 3 & 150,000 & 450,000 \\
\hline Konsumsi & 3 & 261,000 & 783,000 \\
\hline \multicolumn{2}{|c|}{ Jumlah Biaya Kegiatan Pertemuan dengan Orangtua } & $1,233,000$ \\
\hline
\end{tabular}

Berdasarkan hasil perhitungan dari jawaban kuesioner, tercantum hasilnya pada tabel 6 yaitu pada tahun 2019 setiap TK rata-rata mengadakan kegiatan pertemuan dengan orangtua/wali murid sebanyak 3 kali dalam setahun dengan biaya sebesar Rp 1.233.000. Kegiatan parenting ini sangat penting dilaksanakan secara rutin. Menurut Lestari (2019), melalui program parenting orang tua dapat memberikan pendidikan dan stimulasi yang sesuai dengan kebutuhan dan tugas-tugas perkembangan sehingga potensi anak usia dini dapat berkembang dengan maksimal. 


\section{Sosialisasi Perlindungan Anak Bagi Orangtua}

Tabel 7. Pengeluaran untuk Sosialisasi Perlindungan Anak Bagi Orangtua

\begin{tabular}{|l|c|c|r|}
\hline \multicolumn{1}{|c|}{ Komponen Pengeluaran } & Volume per Tahun & $\begin{array}{c}\text { Biaya yang } \\
\text { dikeluarkan }\end{array}$ & Total Biaya \\
\hline Honorarium Narasumber & 2 & 255,000 & 510,000 \\
\hline Konsumsi & 2 & 275,400 & 550,800 \\
\hline \multicolumn{2}{|c|}{ Jumlah Biaya Sosialisasi Perlindungan Anak bagi Orangtua } & $1,060,800$ \\
\hline
\end{tabular}

Perlindungan anak yang dilakukan orangtua sangat penting dalam memberikan rasa aman dan nyaman bagi anak, khususnya dari tindak kekerasan. Menurut Rochmawati, dkk (2018), pencegahan tindak kekerasan terhadap anak dalam keluarga dapat dilakukan dengan mengintegrasikannya dalam pola pengasuhan yang bebas dari tindak kekerasan. Mengingat pentingnya informasi perlindungan anak bagi orangtua maka sebagian besar TK telah melaksanakan sosialisasi perlindungan anak bagi orangtua. Berdasarkan hasil perhitungan dari jawaban kuesioner, tercantum hasilnya pada tabel 7 yaitu pada tahun 2019 rata-rata diperlukan dana sebesar Rp 1.060.800 untuk menyelenggarakan acara tersebut selama 2 kali dalam setahun.

\section{Sosial Kemasyarakatan}

Tabel 8. Pengeluaran untuk Kegiatan Sosial Kemasyarakatan

\begin{tabular}{|l|r|r|r|}
\hline \multicolumn{1}{|c|}{ Bentuk Kegiatan } & Volume per Tahun & \multicolumn{1}{|c|}{$\begin{array}{c}\text { Biaya yang } \\
\text { dikeluarkan }\end{array}$} & \multicolumn{1}{c|}{ Total Biaya } \\
\hline Kunjungan Panti Asuhan & 1 & 350,000 & 350,000 \\
\hline Kunjungan Wisata Edukasi & 4 & 225,000 & 900,000 \\
\hline Kunjungan kepada Anak yang Sakit & 2 & 232,500 & 465,000 \\
\hline \multicolumn{2}{|c|}{ Jumlah Biaya Sosial Kemasyarakatan } & $\mathbf{1 , 7 1 5 , 0 0 0}$ \\
\hline \multicolumn{2}{|c|}{ Sumber: Hasil pengolahan data (dalam rupiah) }
\end{tabular}

Perilaku anak harus distimulus sejak usia dini karena dapat mempengaruhi karakter mereka yang akan mempengaruhi sikap, cara berinteraksi, dan perkembangan karakter (Arifiyanti, 2019). Penelitian tersebut juga menyatakan bahwa perilaku anak dipengaruhi oleh pembiasaan. Pembiasaan yang baik seperti berkunjung ke panti asuhan dan mengunjungi teman yang sakit dapat menstimulus pemikiran anak untuk memiliki sikap peduli dengan sesama. Berdasarkan hasil perhitungan dari jawaban kuesioner, tercantum hasilnya pada tabel 8 yaitu pada tahun 2019 TK mengeluarkan biaya sebesar Rp 1.715.000 untuk keperluan sosial kemasyarakatan. Dalam kegiatan ini juga disertakan kunjungan wisata edukasi yang dapat bermanfaat untuk menambah pengetahuan anak tentang alam dan sekitarnya. Terkait kunjungan wisata edukasi, rata-rata setiap TK mengadakan sebanyak 4 kali dalam satu tahun dengan total biaya sebesar Rp 900.000.

\section{Langganan Listrik, Telp/Internet, Air}

Tabel 9. Pengeluaran untuk Langganan Listrik, Telp/Internet, Air

\begin{tabular}{|c|c|c|c|}
\hline Bentuk Kegiatan & Volume per Tahun & $\begin{array}{c}\text { Biaya yang } \\
\text { dikeluarkan }\end{array}$ & Total Biaya \\
\hline Listrik & 12 & 115,000 & $1,380,000$ \\
\hline Telp/Internet & 12 & 55,300 & 663,600 \\
\hline Air PAM & 12 & 43,700 & 524,400 \\
\hline \multicolumn{3}{|c|}{ Jumlah Biaya Langganan listrik, Telp/internet, PAM } & $2,568,000$ \\
\hline
\end{tabular}

Sumber: Hasil pengolahan data (dalam rupiah) 
Listrik, telp/internet, dan air merupakan sarana pendukung proses pembelajaran dan keberadaannya sangat penting. Berdasarkan hasil perhitungan dari jawaban kuesioner, tercantum hasilnya pada tabel 9 yaitu pada tahun 2019 TK mengeluarkan dana sebesar Rp 2.568.000 untuk membiayai ketiga komponen yang meliputi listrik, telp/internet, dan air PAM. Biaya yang terbesar terletak pada kebutuhan listrik sebesar rata-rata Rp 115.000 per bulan atau Rp 1.380.000 per tahun.

\section{Pemeliharaan Gedung}

Gedung merupakan sarana utama penyelenggaraan pembelajaran. Dalam penelitian ini, definisi gedung juga termasuk bangunan di dalamnya yang meliputi ruang bermain, ruang pendidik dan tenaga kependidikan/administrasi, UKS, kamar mandi, area ibadah, ruang perpustakaan, dan sebagainya. Berdasarkan hasil perhitungan dari jawaban kuesioner, pada tahun 2019 TK mengeluarkan dana untuk pemeliharaan gedung sebesar Rp 1.500.000 dengan rata-rata luas gedung sebesar $200 \mathrm{~m}^{2}$.

\section{Pemeliharaan Peralatan (APE luar dan Perkantoran)}

Tabel 10. Pengeluaran untuk Pemeliharaan Peralatan (APE luar dan Perkantoran)

\begin{tabular}{|l|r|r|r|}
\hline \multicolumn{1}{|c|}{ Komponen Pengeluaran Pemeliharaan } & Volume per Tahun & $\begin{array}{r}\text { Biaya yang } \\
\text { dikeluarkan }\end{array}$ & \multicolumn{1}{c|}{ Total Biaya } \\
\hline APE Ayunan & 1 & 132,500 & 132,500 \\
\hline APE Seluncuran & 1 & 123,700 & 123,700 \\
\hline APE Terowongan & 1 & 53,200 & 53,200 \\
\hline APE Jungkat-Jungkit & 1 & 148,200 & 148,200 \\
\hline APE Balok Titian & 1 & 49,500 & 49,500 \\
\hline APE Tangga Majemuk & & 123,600 & 123,600 \\
\hline & 1 & 127,500 & 127,500 \\
\hline APE Alat Bergelantungan & 1 & 189,600 & 189,600 \\
\hline APE Komedi Putar & 1 & 278,300 & 278,300 \\
\hline Komputer dan alat pendukungnya & 1 & 133,600 & 133,600 \\
\hline Printer & 1 & $\mathbf{1 , 3 5 9 , 7 0 0}$ \\
\hline \multicolumn{2}{|r|}{ Jumlah Biaya Pemeliharaan Peralatan } & & \\
\hline
\end{tabular}

Sumber: Hasil pengolahan data (dalam rupiah)

Alat Permainan Edukatif (APE) sangat diperlukan dalam menunjang proses pembelajaran anak didik khususnya di TK. Berdasarkan hasil perhitungan dari jawaban kuesioner, tercantum hasilnya pada tabel 10 yaitu pada tahun 2019 rata-rata setiap TK mengeluarkan dana untuk pemeliharaan APE luar sebesar Rp 1.359 .700 pada tahun 2019 . Keberadaan APE khususnya APE luar sangat penting dalam upaya peningkatan kerjasama antar anak-anak. Menurut Fauziddin (2016) kerjasama merupakan pola perilaku sosial, semakin banyak kesempatan yang anak miliki untuk melakukan suatu hal bersama-sama, semakin cepat anak belajar melakukannya dengan cara bekerja sama. Dalam komponen pemeliharaan peralatan ini juga dimasukkan untuk pemeliharaan computer dan alat pendukungnya seperti printer, LCD, dan sebagainya yang membutuhkan dana perawatan sebesar Rp 278.300 pada tahun 2019. 


\section{Pengadaan/Pemeliharaan Perlengkapan Kantor}

Tabel 11. Pengeluaran untuk Pengadaan/Pemeliharaan Perlengkapan Kantor

\begin{tabular}{|l|c|r|r|}
\hline \multicolumn{1}{|c|}{ Komponen Pengeluaran Perlengkapan } & Volume per Tahun & $\begin{array}{c}\text { Biaya yang } \\
\text { dikeluarkan }\end{array}$ & Total Biaya \\
\hline Meja dan Kursi Kepala TK (Pemeliharaan) & 2 & 147,800 & 295,600 \\
\hline Meja dan Kursi Guru TK (Pemeliharaan) & 2 & 105,600 & 211,200 \\
\hline Meja dan Kursi Tenaga Administrasi (Pemeliharaan) & 2 & 73,600 & 147,200 \\
\hline Meja dan Kursi Siswa (Pemeliharaan) & 2 & 146,250 & 292,500 \\
\hline & & 112,400 & 112,400 \\
\hline Lemari Dokumen (Pemeliharaan) & 1 & 101,350 & 101,350 \\
\hline Rak Buku (Pemeliharaan) & 1 & 246,300 & 246,300 \\
\hline DDTK (Pemeliharaan/Pembelian) & 1 & 189,650 & 379,300 \\
\hline P3K (Pembelian) & 2 & 467,200 & 934,400 \\
\hline APE Dalam (Pembelian) & 2 & 231,400 & 462,800 \\
\hline Perlengkapan Kebersihan (Pembelian) & 2 & & 487,700 \\
\hline \multicolumn{2}{|c|}{ Jumlah Biaya Pengadaan/Pemeliharaan Perlengkapan kantor } & & $3,670,750$ \\
\hline
\end{tabular}

Sumber: Hasil pengolahan data (dalam rupiah)

Perlengkapan kantor sangat diperlukan untuk menunjang proses pembelajaran. Berdasarkan hasil perhitungan dari jawaban kuesioner, tercantum hasilnya pada tabel 11 yaitu pada tahun 2019 rata-rata setiap tahunnya masing-masing TK mengeluarkan dana sebesar Rp 3.670.750 untuk membiayai komponen tersebut. Adapun biaya terbesar digunakan untuk pembelian APE dalam, sebesar Rp 934.400 pada tahun 2019. APE sangatlah penting dalam menunjang peningkatan kognitif anak. Menurut Joni (2016), kognitif berhubungan dengan tingkat kecerdasan yang mencirikan seseorang dengan berbagai minat terutama ide-ide dan motivasi belajar.

\section{Biaya Satuan Operasional Penyelenggaraan Taman Kanak-Kanak Holistik Integratif}

Berdasarkan hasil perhitungan masing-masing biaya menurut komponennya, maka diperoleh besaran biaya satuan operasional TK Holistik Integratif yang ideal di Indonesia sebesar Rp 5.857.750 dengan rata-rata siswa per TK sebanyak 15 siswa (tabel 12). Sejumlah biaya tersebut, komponen yang terbesar diperuntukkan untuk membiayai gaji guru dan tendik dan komponen yang terkecil diperuntukkan untuk membiayai pengembangan SDM Guru/Tendik.

\section{Tabel 12. Biaya Satuan Operasional TK Holistik Integratif}

\begin{tabular}{|c|c|c|c|c|c|}
\hline No & Komponen Pembiayaan & Driver & Akt. Driver & Cost Driver & Activity Driver Rate \\
\hline 1 & Gaji Guru/Tendik & Jam kerja & 1080 & 56,467 & $60,984,000$ \\
\hline 2 & Pengembangan SDM Guru/Tendik & hari kegiatan & 3 & 286,333 & 859,000 \\
\hline 3 & Penyuluhan gizi seimbang bagi orangtua anak & hari kegiatan & 1 & $1,078,000$ & $1,078,000$ \\
\hline 4 & Penyediaan makanan tambahan anak & anak & 12 & 362,500 & $4,350,000$ \\
\hline 5 & Pemeriksaan kesehatan anak & anak & 12 & 624,000 & $7,488,000$ \\
\hline 6 & Kegiatan pertemuan dengan orang tua/wali murid & hari kegiatan & 1 & $1,233,000$ & $1,233,000$ \\
\hline 7 & Sosialisasi perlindungan anak bagi orangtua & hari kegiatan & 1 & $1,060,800$ & $1,060,800$ \\
\hline 8 & Sosial Kemasyarakatan & hari kegiatan & 1 & $1,715,000$ & $1,715,000$ \\
\hline 9 & Langganan listrik, telp/internet, air & bulan pemakaian & 12 & 214,000 & $2,568,000$ \\
\hline 10 & Pemeliharaan gedung & luas gedung & 200 & 7,500 & $1,500,000$ \\
\hline 11 & Pemeliharaan Peralatan (APE luar dan Perkantoran) & peralatan & 10 & 135,970 & $1,359,700$ \\
\hline 12 & Pengadaan/Pemeliharaan Perlengkapan kantor & alat & 11 & 333,705 & $3,670,750$ \\
\hline \multicolumn{5}{|c|}{ Total Biaya } & $87,866,250$ \\
\hline \multicolumn{5}{|c|}{ Jumlah Anak } & 15 \\
\hline \multicolumn{5}{|c|}{ Biaya Satuan (unit Cost) Anak per Tahun } & $5,857,750$ \\
\hline
\end{tabular}


Dalam penelitian ini juga menghitung variasi dan proyeksi biaya satuan operasional lembaga berdasarkan wilayah dan tahun 2021 dan 2022, yaitu wilayah Indonesia bagian Barat, Indonesia bagian tengah, dan Indonesia bagian Timur. Untuk wilayah Indonesia bagian Barat terdiri dari Provinsi Daerah Khusus Ibukota Jakarta, Jawa Barat, Jawa Tengah, Jawa Timur, Banten, Daerah Istimewa Yogyakarta, Nangroe Aceh Darussalam, Sumatera Barat, Sumatera Utara, Kepulauan Riau, Jambi, Riau, Sumatera Selatan, Bangka Belitung, Lampung, Bengkulu, Kalimantan Tengah dan Kalimantan Barat. Indonesia bagian tengah terdiri dari Provinsi Bali, Kalimantan Utara, Kalimantan Timur, Kalimantan Selatan, Sulawesi Tengah, Sulawesi Barat, Sulawesi Selatan, Sulawesi Utara, Sulawesi Tenggara dan Gorontalo. Indonesia bagian timur terdiri dari Provinsi Maluku Utara, Maluku, Papua Barat dan Papua.

Tabel 13. Proyeksi Biaya Satuan Operasional TK HI Menurut Wilayah, Tahun 2021-2022

\begin{tabular}{|c|c|c|c|c|c|}
\hline \multicolumn{3}{|c|}{2021} & \multicolumn{3}{|c|}{2022} \\
\hline $\begin{array}{c}\text { Indonesia } \\
\text { Bagian Barat }\end{array}$ & $\begin{array}{c}\text { Indonesia } \\
\text { Bagian Tengah }\end{array}$ & $\begin{array}{c}\text { Indonesia } \\
\text { Bagian Timur }\end{array}$ & $\begin{array}{c}\text { Indonesia } \\
\text { Bagian Barat }\end{array}$ & $\begin{array}{c}\text { Indonesia } \\
\text { Bagian Tengah }\end{array}$ & $\begin{array}{c}\text { Indonesia } \\
\text { Bagian Timur }\end{array}$ \\
\hline 6.360 .377 & 6.516 .956 & 9.420 .638 & 6.751 .415 & 6.917 .621 & 9.999 .823 \\
\hline
\end{tabular}

Berdasarkan hasil perhitungan dari hasil kuesioner dengan menggunakan laju inflasi, tercantum pada tabel 13 diperoleh proyeksi angka rata-rata biaya satuan tahun 2021 yang cukup tinggi yaitu sebesar Rp 6.360.377 hingga Rp 9.420.638 per siswa per tahun. Jika melihat besaran bantuan dana BOP PAUD yang diberikan oleh Pemerintah masih sangat jauh dari kebutuhan biaya pendidikan di TK Holistik Integratif, sehingga tidak mengherankan jika banyak orangtua yang mengeluhkan mahalnya biaya pendidikan di TK. Melihat hal ini sebaiknya Pemerintah dapat menjalin kerjasama dengan Swasta untuk bersama-sama membiayai kebutuhan operasional dan investasi TK di masing-masing wilayah.

\section{SIMPULAN}

Biaya satuan operasional selama 1 tahun per siswa untuk TK holistik integratif sebesar Rp 5.857.750, dan besaran biaya satuan operasional untuk TK di Indonesia bagian barat lebih rendah daripada Indonesia bagian tengah dan timur. Berdasarkan hasil simpulan tersebut, maka diberikan beberapa saran kebijakan antara lain (1) menyikapi hal ini sebaiknya praktisi PAUD dapat bersinergi dengan guru untuk bekerjasama dalam penyelenggaraan pembelajaran, pengadaan alat dan bahan pembelajaran, kegiatan ekstrakurikuler dan sebagainya sebagai upaya mengurangi beban biaya operasional yang tinggi (2) dalam menentukan besaran bantuan dana yang diberikan Pemerintah sebaiknya perlu dipertimbangkan besaran biaya satuan operasional agar tujuan pemberian bantuan dana yaitu untuk meningkatkan akses dan mutu dapat tercapai, dan (3) Pemerintah menjalin kerjasama dengan pihak swasta di masing-masing daerah untuk bersinergi membiayai operasional penyelenggaraan TK.

\section{DAFTAR PUSTAKA}

Akdon. (2015). Manajemen Pembiayaan Pendidikan. Bandung: PT. Remaja Rosdakarya. Al, \& Kadri, H. (2011). Efektivitas Dan Efisiensi Pembiayaan Pendidikan. Fip Unp, 23. https://doi.org/https://doi.org/10.31227/osf.io/5ysw4

Anhusadar, L. O. (2016). Kreativitas Pendidikan Di Lembaga PAUD. Al-Ta'dib, 9(1), 76-93.

Arifiyanti, N. (2019). Relationship between Authoritative Parenting Style and Preschools Prosocial Behavior. Jurnal Obsesi: Jurnal Pendidikan Anak Usia Dini, 3(2), 311. https://doi.org/10.31004/obsesi.v3i2.166 
Cardos, I.R. \& Pete, S. (2011). Activity- based costing (ABC) and activity- based management (ABM) implementation- is this the solution for organizations to gain profitability? Romanian Journal of Economics, 32(1(41)).

Chrystiana, N., Mochamad, A. (2014). Komponen Biaya Dan Biaya Satuan Operasi Pendidikan Taman Kanak-Kanak (Studi Kasus Di 3 Taman Kanak-Kanak). Jurnal Akutabilitas Manajemen Pendidikan, 2(1), 70-80.

Cropley. (1999). Tahap-Tahap Perkembangan Kreativitas.

Fauziddin, M. (2016). Peningkatan Kemampuan Kerja Sama melalui Kegiatan Kerja Kelompok Pada Anak Kelompok A TK Kartika Salo Kabupaten Kampar. Jurnal Obsesi : Jurnal Pendidikan Anak Usia Dini, 2(1), 29. https:// doi.org/10.31004/obsesi.v2i1.47

Hasanah, A., \& Muryanti, E. (2019). Pengaruh Penggunaan Media Diorama terhadap Perkembangan Kemampuan Motorik Halus Anak Usia Dini. Aulad: Journal on Early Childhood, 2(2), 1-7. https:/ / doi.org/10.31004/aulad.v2i2.29

Intan Rochmawati, N., \& Waluyo Adhi Budi Susilo, N. (2018). Pencegahan Kekerasan Terhadap Anak Usia Dini di TK IT Bintang Kecil Kota Semarang. In Pernik, Jurnal PAUD (Vol. 1).

Joni. (2016). Peningkatan Kemampuan Kognitif Anak dalam Kegiatan Berhitung dengan Permainan Dadu. Jurnal PAUD Tambusai, 2(1), 1-10. https:// doi.org/https:// doi.org/10.31004/obsesi.v2i1.44

Kebudayaan, K. P. dan. (2011). Model Penyelenggaraan PAUD Terpadu dengan Perpustakaan Mainan. Medan: Medan: Balai Pengembangan Pendidikan Nonformal dan Informal Regional I Medan.

Kementerian Pendidikan dan Kebudayaan. (2003). Undang-Undang No. 20 Tahun 2003 tentang Sistem Pendidikan Nasional (Sisdiknas) dan Penjelasannya. Yogyakarta: Media Wacana Press.

Khotimah, L. (2014). Kesehatan Pada Anak Usia Dini. Buletin PGRA UINSA.

Lestari, N. G. A. M. Y. (2019). Program Parenting Untuk Menumbuhkan Kesadaran Pentingnya Keterlibatan Orang Tua di PAUD. Pratama Widya : Jurnal Pendidikan Anak Usia Dini, 4(1), 8-17. https:/ / doi.org/10.25078/pw.v4i1.1064

Perdana, N. S. (2015). Faktor-Faktor yang Berpengaruh Terhadap Aksesibilitas Memperoleh Pendidikan untuk Anak-Anak di Indonesia. Jurnal Pendidikan Dan Kebudayaan, 21(3), 279. https://doi.org/10.24832/jpnk.v21i3.191

Pidarta, M. (2007). Landasan kependidikan: stimulus ilmu pendidikan bercorak Indonesia. Jakarta: Rineka Cipta.

Rahayu, N., \& Munastiwi, E. (2018). Manajemen Makanan Sehat di PAUD. Jurnal Ilmiah Tumbuh Kembang Anak Usia Dini, 3(2), 65-80. Retrieved from https:/ / www.mendeley.com/catalogue/0b4b0194-02f5-3954-b2b6-bbbbc33914a4/

Syafriani. (2016). Efektifitas Penyuluhan Terhadap Pengetahuan Ibu Balita Tentang Menu Seimbang Balita Di Posyandu Melati Desa Muara Langsat Kuantan Singingi 2016. Jurnal PAUD Tambusai, 2(2), 100-106. https:/ / doi.org/10.31004/obsesi.v2i2.36

Syawalaxa, A. R. I., Fadhlillah, R., Sutopo, W., dan Y. (2019). Analisis Operasional Bongkar Muat Barang Dengan Pendekatan Activity Based Costing Di PT. KALOG Surakarta. Seminar Dan Konferensi Nasional IDEC ISSN: 2579-64292019, E13.1-E13.5. Surakarta.

Trimuliana, I., Dhieni, N., \& Hapidin, H. (2019). Perilaku Religius Anak Usia 5-6 Tahun pada PAUD Model Karakter. Jurnal Obsesi: Jurnal Pendidikan Anak Usia Dini, 3(2), 570. https:// doi.org/10.31004/obsesi.v3i2.251

Ulpha Lisna Azhari and Dedy Achamd Kurniady. (2016). Manajemen Pembiayaan Pendidikan, Fasilitas Pembelajaran, Dan Mutu Sekolah. Jurnal Administrasi Pendidikan, 13(2), 23. 